\title{
Polityka energetyczna rządu wobec sektora odnawialnych źródeł energii w świetle raportu Naczelnej Izby Kontroli oraz Polityki Energetycznej Polski do 2040 roku
}

\author{
Nieautoryzowany zapis wybranych fragmentów dyskusji \\ Seminarium Energetycznego Collegium Civitas 22 stycznia 2019 roku
}

Energy Policy of Polish Government to Renevables Energy Sources from the perspective of the Report of the Supreme Audit Office and Poland' Energy Policy to the Year 2040

Selected parts of discussion during the Collegium Civitas Energy Seminar, January 22, 2019

Abstract

Discussion concerned with following issues:

Energy Policy of Polish Government to Renewable Energy Sources, political support to conventional energy strategy, the future of the hard coal sector, political determinants of European Union climate policy, the participative role of Public Opinion in the process of energy policy creation, the costs of the electric energy production in the different technologies, energy independence of the state.

Keywords - Energy policy, renewable energy sources, climate policy, conventional energy policy, politics 


\section{Paweł Ruszkowski}

Chcę się odnieść do dokumentu Polityka Energetycżna Polski do 2040 roku (PEP 2040). Jako socjolog patrzę na taki dokument jako na przedmiot analizy. Jest to dokument rządowy i w związku z tym on coś nam mówi o zamiarach rządu i o tym, w jakim kierunku ten rząd zamierza ukierunkować rozwój energetyki polskiej, w szczególności elektroenergetyki. Pierwsza teza jest następująca: główną myślą strategiczną programu rządowego jest utrzymanie dominującej pozycji energetyki węglowej.

Podam kilka przykładów. Otóż podstawowym źródłem energii elektrycznej pozostanie węgiel kamienny, udział energetyki węglowej w miksie energetycznym w roku 2030 wyniesie 60\%, a udział odnawialnych źródeł energii (OZE) 27\%. Zacytuję tutaj konkretne sformułowanie: „Potrzeba dywersyfikacji struktury wytwarzania energii elektrycznej będzie przyczyniać się do zmniejszenia roli węgla w bilansie, a jednak bezwzględnie ilościowe wykorzystanie tego surowca przez energetykę zawodową w perspektywie najbliższych kilkunastu lat nie ulegnie znaczącym zmianom" [1, s. 8]. Moim zdaniem przewodnią idea programu rządowego jest przekonanie, że trzeba wiele zmienić, żeby nic się nie zmieniło. Ja tak rozumiem strategię rządu zawartą w tym dokumencie.

W roku 2015 wydobycie węgla kamiennego wynosiło 59,2 mln ton. W 2030 będzie obniżone do 56,4. To jest około 5\%. Czyli jest zmiana typu kosmetycznego. Oto kolejny cytat ilustrujący pro węglową orientację programu rządowego: „Dzięki postępowi technologicznemu nowe oraz modernizowane blogi węglowe cechują się najwyższą sprawnościa, co wpływa na racjonalność i efektywność zużycia surowca oraz na ograniczenie wpływu energetyki na środowisko" [1, s. 8]. Czyli jest to przekonanie o dużym potencjale rozwojowym energetyki węglowej i o tym, że bezpieczeństwo energetyczne państwa w ciagu najbliższych kilkunastu lat może być w oparciu o tę strategię utrzymane.

Kolejna kwestia dotyczy relacji pomiędzy energetyką konwencjonalną a tą ze źródeł odnawialnych. Według PEP 2040 na ekonomikę jednostek wytwórczych, opartych o węgiel, negatywnie wpływa pierwszeństwo wprowadzania do sieci energii z OZE równocześnie energia z węgla obarczona jest kosztami polityki klimatycznej. Według dokumentu rządowego rynek energii elektrycznej został silnie zniekształcony z powodu funkcjonowania na nim subsydiowanych, odnawialnych źródeł energii OZE charakte- 
ryzujących się dużą niestabilnością pracy. Można zatem powiedzieć, że perspektywa strategiczna dokumentu rządowego polega na traktowaniu OZE jako zewnętrznych zagrożeń energetyki konwencjonalnej.

W tym kontekście warto postawić pytanie, jakie siły polityczne i społeczne forsują tę opcję węglową? Czy faktycznie środowisko górnicze będzie walczyć na barykadach?

W roku 2017 miałem dzięki uprzejmości kolegi Grajcarka prowadzić badania w kopalni „Knurów - Szczygłowice” w formie panel focusowego z udziałem dwunastu sztygarów z tejże kopalni. To wszystko są ludzie poniżej 40-stki, wszyscy mają wykształcenie wyższe, jeden ma doktorat. Naprawdę byłem bardzo pod dużym wrażeniem wysokiego poziomu tej dyskusji. Jakie są konkluzje? Otóż ci ludzie są głęboko przekonani, że to jest koniec górnictwa. W perspektywie 10-15 lat górnictwo i przestanie odgrywać wiodąca role w wytwarzaniu energii elektrycznej. Oni na przykład mówią: „my już naszych synów nie chcemy posyłać do górnictwa, niech oni idą do innych szkół, na inne uczelnie, bo my uważamy, że to jest bezsensu". Pytam dalej: jak wy do tego podchodzicie, jako pracownicy kopalni? A oni mówią tak: „Proszę pana, nikt nam nic nie zaproponował. Nie ma tu w ogóle o czym rozmawiać, w związku z tym, my będziemy siedzieli tak długo jak długo da się siedzieć, być może dosiedzimy do emerytury”.

Moim zdaniem rozwiązanie tego strategicznego dylematu - ile węgla? Ile OZE? wymaga rozmów i negocjacji z udziałem różnych środowisk społecznych: górników, związkowców, ekspertów technicznych, ale również socjologów, ekonomistów, politologów. Cały czas mamy dwie zupełnie odmienne koncepcje. Jedna koncepcja to energetyka oparta o źródła odnawialne, druga oparta o węgiel. Trzeba więc rozmawiać o tym, w jaki sposób dojść do modelu mieszanego, w którym stopniowo schodzimy z węgla, a pojawiają się inne źródła energii, w tym przede wszystkim odnawialne.

Jeśli rozmawiamy o czynniku politycznym, czyli zagrożeniu bytu materialnego górników i ich rodzin, to trzeba wrócić do pewnych koncepcji, które już były z powodzeniem stosowane. Można wprowadzić pomostowe, czyli stopniowe zmniejszanie zatrudnienia w górnictwie w sposób naturalny, z uwzględnieniem np. pięcioletniego okresu, kiedy górnik dostaje $70 \%$ pensji za to, że nie fedruje.

Czy to zyska akceptację społeczności górniczej?

Od tego właśnie jest stół negocjacyjny, od tego są eksperci, temu służą badania socjologiczne. 


\section{Kazimierz Grajcarek}

Jak wiecie jestem związkowcem, więc ja trochę inaczej na tę sprawę patrzę. Jest jednak taki punkt, na który wszyscy musimy popatrzeć, obojętnie czy jesteśmy profesorami, prostymi ludźmi, związkowcami czy kimkolwiek. A mianowicie to, że jesteśmy Polakami i że jest interes Rzeczypospolitej. Jeśli zapomnimy o interesie Rzeczpospolitej, a będziemy mówić o jednej, drugiej czy trzeciej wyrywkowej sprawie, to się wyślizgamy.

Bardzo mnie zaniepokoiło to, co powiedział pan Andrzej Sikora. A mianowicie, że ten dokument rządowy jest do niczego. Szanowni Państwo, przeglądałem wiele dokumentów rządowych dotyczących energetyki. Żaden z nich nie został zrealizowany. Ja nie patrzę na ten dokument jak na coś, co jest nie warte. Ja patrzę na ten dokument z obawa, że coś tam jest dobrego zapisane i być może nie zostanie zrealizowane. I to mnie nie pokoi, że nie zostanie zrealizowany ten projekt.

Z punktu widzenia Rzeczypospolitej teraz powiem. Sprawy właśnie polityki klimatycznej stawiane są mniej więcej tak, jak pan postawił sprawę. A mianowicie, że do stołu negocjacyjnego dotyczącego polityki klimatycznej świata, Europy i Polski nie są dopuszczani ci, którzy mają inne zdanie niż zwolennicy głównego nurtu. Związkowcy przed Konferencją Narodów Zjednoczonych w sprawie Zmian Klimatu, Katowice 2018 (COP 24) zaprosili do stołu negocjacyjnego wszystkich naukowców, niezależnie od tego, czy ich poglądy odpowiadają kryteriom poprawności politycznej, czy nie. I co się wydarzyło? Otóż część polityków odmawiała udziału w tym spotkaniu. Dlaczego? Jakim prawem ty, nawet polityk, masz prawo oceniać, czy ten profesor jest mądry czy nie? Ja mówię - stary, było tysiące naukowców, którzy mówili, że ziemia jest płaska. A tylko jeden Kopernik mówił, że jest okragła.

Mówimy - rezygnujemy z węgla. Zasobów węgla mamy na jakieś 600 lat i możemy z tych zasobów korzystać. W sytuacji bardzo trudnej, związanej z bezpieczeństwem świata, mamy zapewnione swoje źródło energii. My nie chcemy swojego zaorać, zakopać i uzależniać się. Po podpisaniu porozumienia z Kioto była mowa o tym, że dążymy do dekarbonizacji, obniżenia emisji $\mathrm{CO}_{2}$ i tak dalej. Tymczasem żadne państwo nie zmniejszyło de facto emisji $\mathrm{CO}_{2}$.

Związkowcy proponują analizę tak zwanego śladu węglowego. Moim zdaniem emisja $\mathrm{CO}_{2}$ to przecież nie jest tylko to, co tu wyemituję w tym miejscu w moim kraju. Ale jeśli przywożę do mojego kraju wyroby z zagranicy, to $\mathrm{CO}_{2}$ zostało gdzieś wyemitowane. 
Popatrzmy, co zrobili Niemcy. 40 lat temu rozpoczęli likwidację swojego górnictwa węgla kamiennego, zakończyli w zeszłym roku. Jak rozpoczynali te działania, to produkowali $60 \mathrm{mln}$ ton, a teraz $60 \mathrm{mln}$ ton sprowadzaja. Przy okazji zlikwidowali 40 tysięcy miejsc pracy.

\section{Głos z sali}

Panie Przewodniczący, ja uściślę, w roku 2018 zgodnie z Eurostatem, Niemcy sprowadzili 70 mln ton węgla kamiennego.

\section{Kazimierz Grajcarek}

Postawmy pytanie: na czym ta gra polega? W roku 2014 przed porozumieniem w Paryżu, państwa Unii Europejskiej importowały $176 \mathrm{mln}$ ton węgla. Natomiast w roku 2018 import wyniósł 215 mln ton. Czy nie zadajecie sobie Państwo pytania, kto tu jest ogrywany i dlaczego? Mówicie Państwo o cenie energii elektrycznej, ekonomii i tak dalej. Ja to mówię z mojego punktu widzenia o ekonomii, ceny węgla. Przecież jak się kształtuje cena węgla w Europie? Są trzy porty Amsterdam, Rotterdam, Antwerpia. Sumę cen węgla w tych portach dzieli się przez 3 i to jest obowiązująca cena w Unii Europejskiej tzw. węgla wskaźnikowego.

Jeśli Polska wyprodukuje węgiel i chce go sprzedać po 65 zł, to Komisja Europejska wysyła do nas kontrolę, czy sprzedaje energię po cenie danej rynkowej. A kto sprawdził tych producentów? Skąd oni wzięli tę cenę? Czy to jest cena dumpingowa, czy podwyższona? Proszę Państwa, my związkowcy patrzymy również i na tę stronę. Jeśli weźmiemy cenę, bo Państwo tutaj podajecie cenę energii elektrycznej i koszt ceny energetycznej. A my cenę energii elektrycznej rozkładamy na cenę produkcji energii elektrycznej i cenę jej sprzedaży.

W roku 2014 produkcja, cena wyprodukowania 1 megawatogodziny w Polsce to było 80 złotych, a cena sprzedaży 200 złotych. Czyli co to było, co wchodziło na tę składową cenę produkcji węgla - robocizny i tak dalej. Skąd się bierze cena energii? Poprosiłem producentów oficjalnie, jako przewodniczący Krajowego Sekretariatu Górnictwa i Energetyki, o cenę kosztów produkcji, przesyłu i sprzedaży z OZE. Do dnia dzisiejszego nie otrzymałem takiej informacji. 
Niech zatem odnawialne źródła energii elektrycznej działają wtedy, kiedy moga, kiedy jest słońce, kiedy jest wiatr. Ale wtedy, kiedy nie pracują i nie dostarczają energii elektrycznej, to niech kupią tę energię w elektrowni i niech ją sprzedadza, proszę bardzo. Ale ktoś musi przecież zapłacić za podtrzymanie systemu. Przecież OZE nie podtrzyma nam systemu. Jak jest wiatr, to w pierwszej kolejności państwo od niego musi kupić tą energię elektryczna, ale jak nie ma, to nie dostarcza tej energii, to zgoda, powinien kupić w elektrowni, zapłacić za podtrzymanie systemu, proszę bardzo, ja się z tym zgadzam.

Zwiazkowcy zaproponowali, że jeśli mamy stawiać już wiatraki, to kupujmy te technologie, to my budujmy te wiatraki, żeby nasi pracownicy mieli pracę, a my jesteśmy tylko montownią. Niestety, ani rząd, ani inne środowiska nie wsparły naszego projektu.

\section{Adam Krynicki}

Proszę Państwa, ja myślę, że polska energetyka jest w stanie głębokiego kryzysu, jest w stanie katastrofy. I ta katastrofa została dzisiaj przedstawiona przez pierwszych prelegentów: pana prezesa i pana doktora. Istotne dla oceny sytuacji jest to, że nikt nie wie, jak z tej katastrofy wyjść. Co więcej, nie ma od lat w Polsce żadnej strategii energetycznej, bo to co było zrobione w roku 2009, też było dyskusyjne.

Jednocześnie trzeba powiedzieć, że strategii energetycznej nie można zmieniać co chwilę. Strategia musi być na długi okres z uwagi na długi okres inwestycyjny i długi okres eksploatacji inwestycji, które się wiąża z energetyka. Mowa jest w tej chwili o tym, że w tym planie, który rząd zaproponował w 33 roku będzie energetyka jądrowa. To jest bardzo wattpliwe. Ten dokument rządowy nie budzi zaufania czytelnika, ponieważ nie wiadomo, które zamierzenia są realne. Pan Przewodniczący odwoływał się do interesu narodowego, to jest oczywiście interes narodowy, żebyśmy mieli jakąs spójną, mądrą strategię energetyczną.

Moim zdaniem zebrane w ramach tego Seminarium grono ekspertów powinno społeczeństwu pokazać, jak mogą wyglądać scenariusze katastroficzne, bo one mogą nastąpić. Również partie polityczne powinny uświadomić sobie, że to jest sprawa, nad która nie można przejść obojętnie. Musimy mieć spójną wizję tego, co chcemy osiagnnąć, jakie będą tego koszty, jak to zostanie zapłacone. Nic na ten temat nie wiemy i sądzę, że przy tej postawie rządu, nie będziemy wiedzieć dalej. Nie wiem, czy my jesteśmy w stanie 
jako grono coś zaproponować na zewnątrz, bo ta sprawa jest niezwykle trudna. Niezwykle, bo widzimy te różne uwarunkowania i społeczne i techniczne i ekonomiczne. Ale w każdym razie uważam, że powinniśmy starać się taką dyskusję zainicjować.

\section{Jarosław Pałasz}

Bardzo cennym przyczynkiem do dyskusji było przesłanie przez pana profesora Mielczarskiego materiału, który pokazuje jakby fizyczne ograniczenia związane z utrzymaniem bezpieczeństwa pracy systemu. Tam był bilans zarówno mocy, jak i energii. Wydaje mi się, że to jest absolutna podstawa, poniżej której nie można schodzić. Ten system to jest tak jak sacrum i profanum. Bezpieczeństwo systemu, czyli ta część związana z zachowaniem bilansu mocy, jest absolutną podstawa. To, że będą jednostki wytwórcze, które będa produkowały, które będą gotowe do produkcji energii elektrycznej, to jest absolutnie pewne. To nie jest powiedziane, że one muszą 100\% czasu poświęcać na produkcję. Poprzez to, że wprowadzamy źródła odnawialne, to ich produkcja energii jest jakby redukowana, w tym samym czasie.

Jeżeli można zastapić źródła konwencjonalne źródłami odnawialnymi, to trzeba to robić. To jest nie tylko kwestia, czy jakiś inwestor zarobi na tej energii, którą wyprodukuje z OZE, ale przede wszystkim nie zostaną spalone te paliwa, które tak naprawdę przyczyniają się do emisji tych wszystkich szkodliwych gazów, które wpływają negatywnie na stan bezpieczeństwa zdrowotnego człowieka.

I tutaj jeżeli chodzi o energetykę, bo było takie twierdzenie, że ta energetyka nie jest traktowana jako istotny element polityki państwa. Energetyka czy w ogóle system elektroenergetyczny i powiedzmy, pochodna tego, jest wpisana jako jedna z infrastruktur krytycznych, w ustawie o infrastrukturze krytycznej, jak zdrowie, jak system bankowy, jak inne media. I to nie jest prawda, że tego nie ma. To wszystko po prostu jest w wielowymiarowym jakby spojrzeniu brane pod uwagę, tylko trzeba pozwolić zrozumieć ludziom, którzy się tym zajmują o co tutaj chodzi. Żeby nie było takich po prostu twierdzeń, że nie będziemy po prostu ograniczać produkcji energii z węgla, bo to daje korzyści jakimś innym zagranicznym powiedzmy inwestorom, czy powiedzmy takim jednostkom, które chcą doprowadzić do destabilizacji państwa.

I jak jest ta stabilność, bezpieczeństwo związane z zachowaniem systemu elektroenergetycznego [...], będzie trwało w długiej perspektywie, zawsze będzie. Czyli, jeżeli 
nawet przyjdzie energia $z$ atomu, ona oczywiście zrobi wyrwę. Tak naprawdę energia z atomu, jak przyjdzie, to zmieni trochę układ sił i nie sądzę, żeby to było kosztem energetyki odnawialnej, bardziej to będzie kosztem produkcji energii z węgla - czy to będzie węgiel kamienny, czy węgiel brunatny - w każdym bądź razie energetyka jądrowa na pewno zastąpi energetykę konwencjonalną bazującą na węglu.

Dziękuję bardzo.

\section{Tomasz Kowalak}

Zgadzam się z panem Przewodniczącym co do jednego, priorytetu, mianowicie interesu Rzeczypospolitej. Moim zdaniem interes Rzeczpospolitej trzeba ujmować w trzech aspektach: pierwszy - to jest zdrowie obywateli, drugi - to jest konkurencyjność gospodarki, a trzeci - to jest bezpieczeństwo polityczne.

Moją konwencję patrzenia na świat można przedstawić przez odwołanie się do perspektywy żaby i bociana. Dzisiejsza dyskusja odbywa się z pozycji żaby. Każdy z nas skupia się na swoim polu widzenia, ale między tą trawą i tymi krzaczkami. Tyle ile widzi, na ile pozwala nam długość jego szyi, mówiąc tak obrazowo. Bez żadnego przytyku, to jest naturalne. Natomiast bocian patrzy na tę samą panoramę, ale z innej perspektywy i dostrzega to, czego żaba nie widzi, bo jej coś zasłania. Z takiej perspektywy bociana chciałbym się skupić na tych aspektach interesu Rzeczpospolitej, jakie stoją przed sektorem energetycznym, na razie nie opowiadając się za żadnym z modeli.

Pierwsza jest perspektywa kosztowa. Ile kosztuje dana technologia czy uzyskanie tego produktu, jakim jest zapewnienie czystej energii, zapewnienie tej pewności uzyskania zasilającego. Tylko, że te koszty mamy niestety bardzo mocno rozbite. Bo są to koszty bezpośrednie, czyli koszty majątku i technologii, koszty zmienne i koszty zewnętrzne, ale jawne w postaci konsekwencji konieczności jej przetransportowania od źródła do odbiorcy, czyli sieci. W tym przypadku znowu mamy koszty majątku i koszty zmienne działania sieci, ale też mamy koszty różnic bilansowych. To są koszty zmienne sieci.

Mamy też pewną kategorię kosztów zewnętrznych ukrytych. Te koszty zewnętrzne potrafią być miażdżąco wysokie, jeżeli tylko zechce się je zobaczyć, to są koszty utraty zdrowia, koszty skutków korozji, cały szereg konsekwencji tego, że pojawiają się w powietrzu określone związki chemiczne na przykład. To nie chodzi tylko o $\mathrm{CO}_{2}$, które jest sztandarowym wskaźnikiem, istotnym w tym klimatycznym, globalnym rozumieniu. 
Natomiast w ujęciu regionalnym, krajowym, dużo ważniejsze są te pozostałe produkty działalności.

Druga perspektywa to jest perspektywa techniczna, która jest analizowana w kilku wymiarach. Jest to zarówno umiejętność i możliwość złożenia bilansu mocy, jak również ryzyko zakłóceń w procesie fizycznego dostarczenia energii, na przykład z powodów klimatycznych.

Perspektywa polityczna dotyczy niezależności energetycznej. Niezależność to poczucie, że nikt nas nie zaszantażuje. Import węgla, import gazu, import paliwa, uranu to są wszystko czynniki, które są zagrożone tym, że ktoś dany kurek zakręci. Ośmielę się powiedzieć, że nasze rodzime złoże węgla, które są wskazywane przez polityków jako fundament bezpieczeństwa energetycznego, też nie są od tego wolne. Proszę sobie przypomnieć strajk bełchatowski i teraz nie tak dawno strajk JSW, który pokazał, jak łatwo jest narzędziami wpływów politycznych de facto zdestabilizować dostępność tego co mamy pod nogami.

Na gruncie tych ryzyk politycznych trzeba znowu wrócić do aspektu technicznego. Na szczęście myśmy jeszcze tego nie doświadczyli, ale na Krymie już nie tak daleko od Polski już się zdarzyło. Po prostu wycięcie linii zasilającej półwysep z kontynentu. Ktoś coś podłożył, coś podciął i nie było. A energetyk wie, jak łatwo jest system położyć działając w sposób taki zorganizowany w pojedynczych kilku miejscach.

W tych trzech aspektach trzeba przeanalizować również różne technologie pod kątem ich stopnia rozproszenia. Technologie wielkoskalowe bardzo skupione, średnioskalowe $\mathrm{i}$ te drobne, rozproszone zupełnie. Bo każda z nich w każdym z tych aspektów - mimo że technologia jest ta sama - technologicznie i fizycznie będzie się zachowywała inaczej. Będzie kreowała różne koszty, różne ryzyka, różne konsekwencje. I dopiero z takiej analizy - mając ją rozpisana, że tak powiem, na stole - dopiero jest sens podejmowania decyzji strategicznych, decyzji kierunkowych, które są tak bardzo potrzebne.

Kolejna sprawa, którą trzeba przedyskutować, dotyczy rynku energii. Czy ten rynek, jaki mamy, jest rynkiem konkurencyjnym w sytuacji, kiedy towarzyszą mu gigantyczne koszty, gdy towarzyszą mu również gigantyczne dopłaty w najrozmaitszych formach do jego funkcjonowania? Czy to jest rynek konkurencyjny i czy w takim razie te dotacje do OZE go zakłócają, czy stanowią jedynie próbę złagodzenia skutków tego, że ono już jest zdeformowane? Otwarte pytania, nie chcę ich tutaj rozstrzygać. 


\section{Literatura}

[1] Ministerstwo Energii (2018), Polityka Energetyczna Polski do 2040 roku (PEP 2040), https://www.gov.pl/documents/33372/436746/PEP2040_projekt_v12_201811-23.pdf/ee3374f4-10c3-5ad8-1843-f58dae119936 